\title{
DETERMINATION OF THE RELATIONSHIP BETWEEN ORGANIC FARMING AREA AND AGRICULTURAL ADDED VALUE IN SOME EUROPEAN UNION COUNTRIES WITH PANEL ARDL ANALYSIS
}

\author{
ÇUKUR, F. ${ }^{1}-$ Ișin, F. ${ }^{2}-$ ÇUKUR, T..$^{*}$ \\ ${ }^{I}$ Department of Management and Organization, Milas Vocational School, Muğla Sitkı Koçman \\ University, 48200 Milas, Muğla, Turkey \\ ${ }^{2}$ Department of Agricultural Economics, Agricultural Faculty, Ege University, 35100 Bornova, \\ İmir, Turkey \\ ${ }^{3}$ Department of Marketing and Advertising, Milas Vocational School, Muğla Sitkı Koçman \\ University, 48200 Milas, Muğla, Turkey \\ *Corresponding author \\ e-mail: tayfun.cukur@hotmail.com; phone:+90-252-211-3263; fax: +90-252-211-1879 \\ (Received $1^{\text {st }}$ Oct 2021; accepted $17^{\text {th }}$ Jun 2021)
}

\begin{abstract}
In the current study, the relationship between organic farming area and agricultural added value in some European Union countries was examined for the period of 2010-2018. Germany, Austria, France, Spain, Italy, Greece, the Netherlands, Denmark and Sweden were included in the study. Dynamic panel ARDL model was used. In the countries examined according to the Pooled Mean-Group (PMG) estimator, a significant positive relationship was found between organic farming area and agricultural added value in the long-term. Since a positive correlation was found between organic farming area and agricultural added value in the study, it was concluded that that organic farming areas, correspondingly, organic agricultural production should be increased in order to increase agricultural added value. In the study, a bidirectional causality relationship was also determined between agricultural added value and organic farming area. Keywords: cointegration test, cross-section dependence test, unit root test, homogeneity test, PMG
\end{abstract}

\section{Introduction}

Increasing world population and industrialization have created a significant pressure on the environment and natural resources. Chemical pesticides and fertilizers have been used extensively in order to feed the increasing population. Mankind has turned to conventional agricultural practices in order to meet the demand for agricultural products and increase their production. This has led to significant increases in the amount of agricultural production, and the amount of food and fibre production increased. However, the intensive use of inputs in agriculture has led to the deterioration of soil structure and land degradation. Thus, it has gained importance to develop environmentally friendly production methods that produce without the use of chemicals, do not harm the environment and natural resources, and are based on sustainability in production. On the other hand, the increase in people's demands for healthy food has led to the development of organic agriculture in the world. Organic agriculture has come to the fore around the world due to the observance that materials used and practices performed to increase yield in agricultural production harm the environment in different ways and due to the increase in environmental concerns (Bahsi, 2020). 
Organic agriculture is a production system that sustains the health of soils, ecosystems, and people. It relies on ecological processes, biodiversity, and cycles adapted to local conditions, rather than the use of inputs with adverse effects. Organic agriculture combines tradition, innovation and science to benefit the shared environment and promote fair relationships and a good quality of life for all involved.

The four principles of organic agriculture are:

- Sustaining and enhancing the health of the soil, plants, animals, humans, and the planet as one and indivisible.

- It should be based on living ecological systems and cycles, and work with them, emulate them and help sustain them.

- Building on relationships that ensure fairness with regard to the common environment and life opportunities.

- Managing in a precautionary and responsible manner to protect the health and wellbeing of current and future generations and the environment (Cukur, 2015).

Organic production can be defined as a system that is carried out by using methods that reduce the damage to the environment as much as possible and is subject to the control of authorized institutions at every stage of the production and consumption chain (Ayla and Altıntaş, 2017).

Agricultural added value is to create an improvement in the physical condition and material value of the agricultural product produced. The improvement in the value of the agricultural raw material or product also adds originality to the product (Akyol, 2018). The agricultural sector provides added value to the country's economy by supplying the necessary raw materials for industrial production as well as meeting the need for animal and plant foodstuffs required for nutrition. Added value represents the difference between the monetary value of goods and services produced and the inputs used in their production. From a macro point of view, agricultural added value refers to the numerical net production reached as a result of the difference between the sum of the outputs in the agricultural sector and that of the inputs (Erdinç and Aydınbaş, 2021). There are two ways to increase agricultural added value. While the first of these is to widen the difference between gross output and inputs subject to production by increasing production efficiency, the other is to increase the margin between the gross output value and the cost of intermediate inputs as a result of changing the amount, function and shape as well as the characteristics of the product and production method (Akyol, 2018).

In the current study, the relationship between agricultural added value and organic farming area in some European Union countries was examined for the period of 2000-2018.

\section{Materials and Methods}

Agricultural added value (agriculture, forestry, fisheries) data of the countries used in the study were obtained from the Food and Agriculture Organization of the United Nations (FAO), and organic agricultural data were obtained from the Research Institute of Organic Agriculture (FIBL). Agricultural added values of the countries are in US\$ obtained with the fixed prices of 2015. The organic agricultural areas of the countries represent the share $(\%)$ of the organic agricultural area in the total agricultural area. The years 2010-2018 were the period investigated in the study. Considering the data availability criterion, Germany, Austria, France, Spain, Italy, Greece, the Netherlands, Denmark and Sweden were included in the study. 
In the current study, cross-section dependence test, unit root test, homogeneity test, panel Granger causality test and ARDL cointegration test were applied. In the study, panel data were used instead of time series. Due to the simultaneous presence of time series and cross-section data observations, the panel data allows the researcher to work with more data. In this case, the number of observations and thus the degree of freedom increase. Thus, the degree of multicollinearity between explanatory variables decreases and the efficiency and reliability of econometric estimates increase. In addition, the use of panel data also allows the analysis of economic problems that cannot be solved with only crosssection data or time series data (Tatoğlu, 2021). ARDL model is being used for decades to model the relationship between economic variables in time series analyses (Kripfganz and Schneider, 2016). In the analysis of the collected data, Stata program was used.

\section{Results}

\section{Agricultural added values and share of organic farming areas of the countries}

Agricultural added values of the countries examined are shown by years in Figure 1. In general, agricultural added values follow a stagnant course. As of 2018, the countries with the highest agricultural added value are France, Italy and Spain.

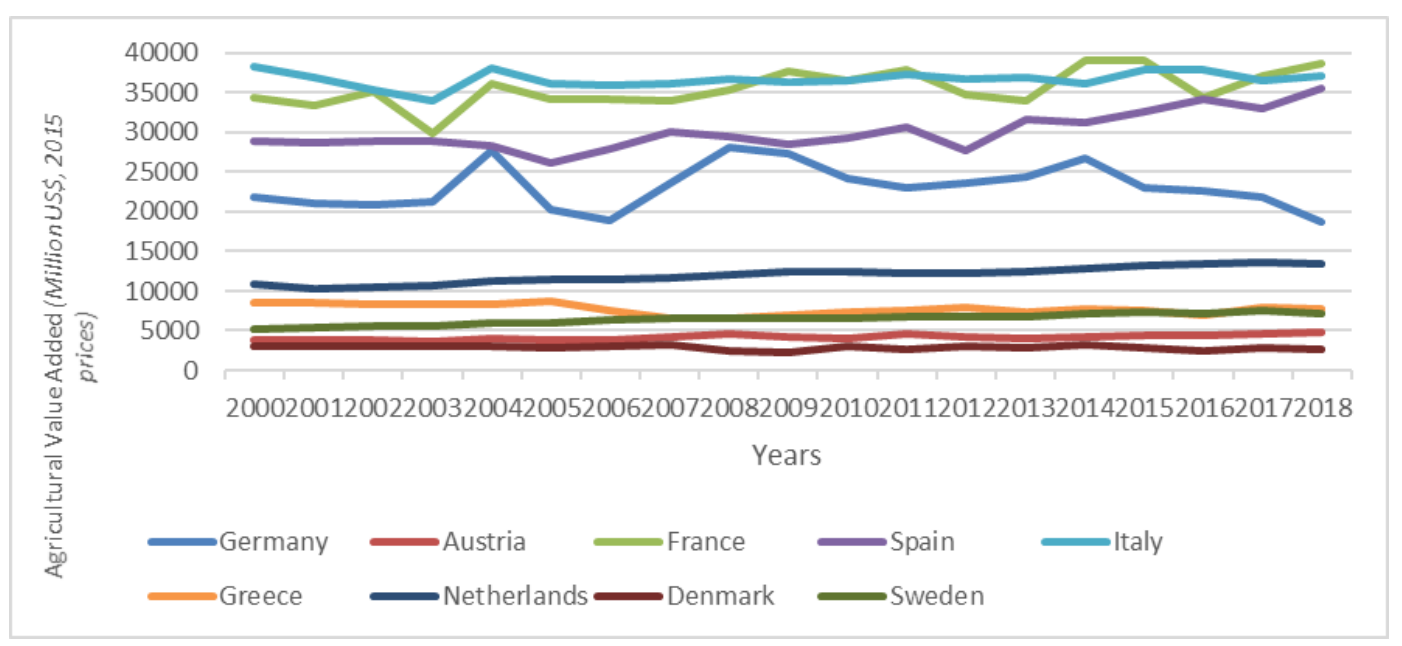

Figure 1. Agricultural added values of the countries (Million US\$, 2015 prices) (FAO, 2021)

The share of organic farming areas (\%) in the total agricultural area of the examined countries is shown in Figure 2. It can be said that organic farming areas tend to increase over time in all the countries. As of 2018, the countries with the highest share of organic farming areas in the total agricultural area are Austria, Sweden and Italy.

\section{Cross-section dependence results}

Cross-section dependence means that there is a correlation between the error terms calculated for each unit of the panel data model (Tatoğlu, 2021). The CD test was used to test the cross-section dependence in the study. The CD test is formulated as follows (Pesaran, 2004). 


$$
C D=\sqrt{\frac{2 T}{N(N-1}}\left(\sum_{i=1}^{N-1} \sum_{j=i+1}^{N} \hat{p}_{i j}\right)
$$

As seen in Table $1, \mathrm{p}$ values are smaller than 0.05 . In other words, the $\mathrm{H}_{\mathrm{o}}$ hypothesis, which accepts that there is no cross-section dependence, is rejected. According to the test results, there is cross-section dependence in the series.

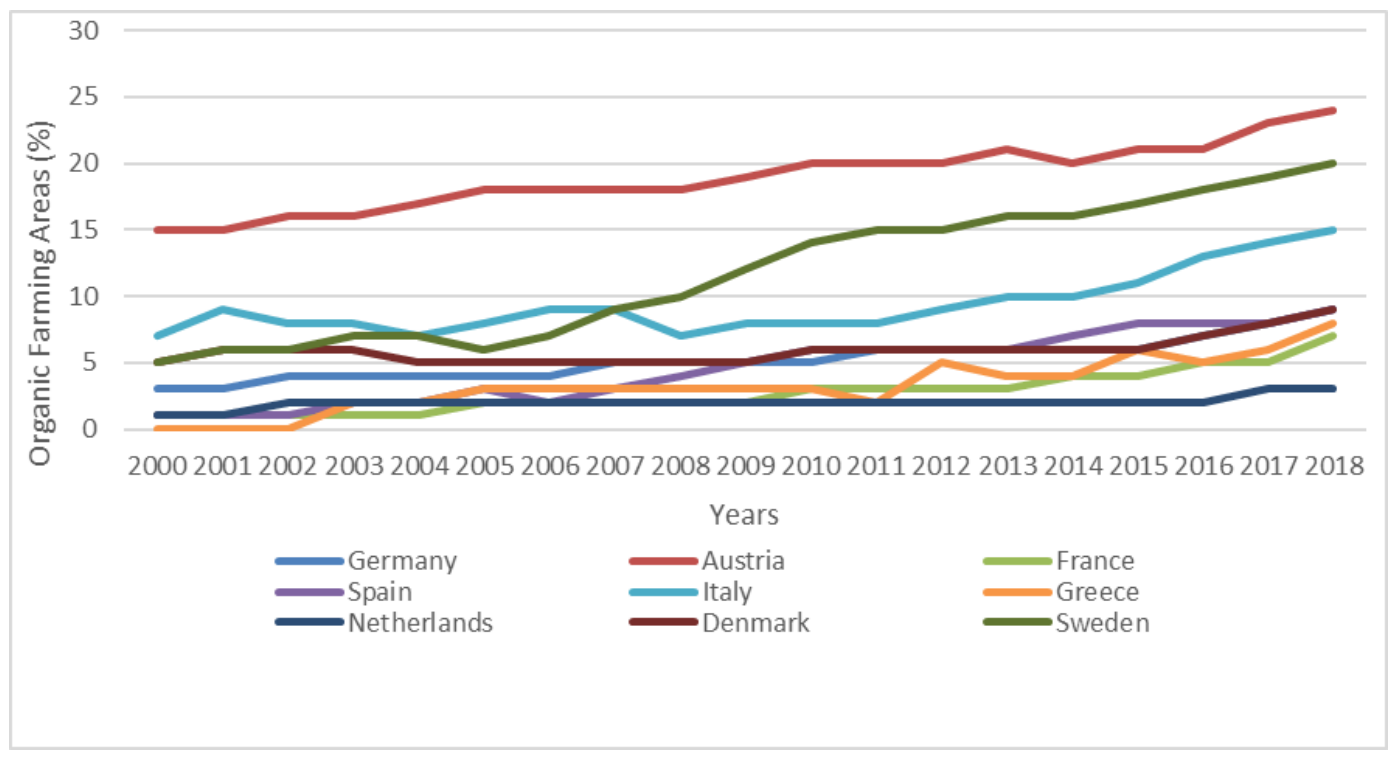

Figure 2. Share of organic farming areas (\%) (FIBL, 2021)

Table 1. Cross-section dependence test

\begin{tabular}{c|c|c|c|c}
\hline Variable & CD-test & p-value & corr. & abs(corr) \\
\hline value_added & 4.22 & 0.000 & 0.161 & 0.407 \\
organic_area & 21.61 & 0.000 & 0.826 & 0.826 \\
\hline
\end{tabular}

\section{Unit root test results}

Since there is cross-section dependence between the series in the study, it will be appropriate to work with second generation unit root tests that take this situation into account. For this reason, the Fisher Extended Dickey Fuller Panel Unit Root test was used in the study.

The Dickey Fuller test is illustrated in theory and practice as follows:

$$
\Delta Y_{t}=\delta Y_{t-1}+u_{t}
$$

(constant and no trend)

$$
\Delta Y_{t}=b_{0}+\delta Y_{t-1}+u_{t}
$$

(constant term and no trend) 


$$
\Delta Y_{t}=b_{0}+b_{1} t+\delta Y_{t-1}+u_{t}
$$

By finding constant term and trend regressions in addition to these, MacKinnon critical values are obtained with the series $\tau$ or DF statistics.

If the error term is with ${ }^{u_{t}}$ autocorrelation, then the Equation (5) is written as follows;

$$
\Delta Y_{t}=b_{0}+b_{1} t+\delta Y_{t-1}+\alpha_{i} \sum_{i=1}^{m} \Delta Y_{t-i}+u_{t}
$$

Here, lagged difference terms are used and the number of lagged difference terms is usually determined empirically. The main purpose of arranging the equation in this way is to include the terms that will ensure that the error term is free of autocorrelation in the model. Here, the null hypothesis is $\mathrm{P}=1$ or $b=0$. In other words, there is a unit root in $\mathrm{Y}$ and in this case, $\mathrm{Y}$ cannot be said to be stationary. If the DF test is applied to the models as the ones in equation (4), it is called the extended Dickey-Fuller (Augmented DickeyFuller) test, that is, the ADF test. The critical values of the test statistics of these tests are the same (Altun, 2017).

In the test run for the organic area series, the $\mathrm{H}_{\mathrm{o}}$ hypothesis is "all units contain a unit root". When the p values are examined, it is seen that this hypothesis is accepted. That is, the organic area series contains a unit root (Table 2).

Table 2. Fisher ADF panel unit root test results for organic area series

\begin{tabular}{c|c|c}
\hline & Statistic & p-value \\
\hline Inverse chi-squared (18) P & 19.3055 & 0.3732 \\
Inverse normal Z & 0.1066 & 0.5424 \\
Inverse logit t (49) L* & 0.4243 & 0.6634 \\
Modified inv. chi-squared Pm & 0.2176 & 0.4139 \\
\hline
\end{tabular}

Since the organic area series contained a unit root, the model was reconstructed by taking the first difference. When the results presented in Table 3 were examined, it was determined that the first difference organic area series became stationary.

Table 3. Fisher ADF panel unit root test results for organic area

\begin{tabular}{c|c|c}
\hline & Statistic & p-value \\
\hline Inverse chi-squared (18) P & 81.5346 & 0.0000 \\
Inverse normal Z & -6.5227 & 0.0000 \\
Inverse logit t (49) L & -7.4993 & 0.0000 \\
Modified inv. chi-squared Pm & 10.5891 & 0.0000 \\
\hline
\end{tabular}

In the test run for the agricultural value added series, when the $\mathrm{p}$ values are examined, it is seen that this hypothesis is rejected. In other words, it is determined that the value added series is stationary (Table 4). 
Table 4. Fisher ADF panel unit root test results for the agricultural value added series

\begin{tabular}{c|c|c}
\hline & Statistic & p-value \\
\hline Inverse chi-squared (18) P & 57.0006 & 0.0000 \\
Inverse normal Z & -3.3437 & 0.0004 \\
Inverse logit t (49) L & -4.3705 & 0.0000 \\
Modified inv. chi-squared Pm & 6.5001 & 0.0000 \\
\hline
\end{tabular}

\section{Homogeneity test}

In panel data studies, the homogeneity or heterogeneity of the coefficients is an important factor in determining the cointegration and causality analyses to be made. While homogeneity refers to the state where the slope coefficients calculated for units such as all countries/regions, etc., are equal to $\beta$, which is a single slope coefficient, heterogeneity refers to the state where at least one of the $\beta$ s belonging to the units is different (Gül and İnal, 2017). The homogeneity test developed by Pesaran and Yamagata (2008) was used in the current study. In the homogeneity test, the $\mathrm{H}_{\mathrm{o}}$ hypothesis is "the slope coefficients are homogeneous". When the $\mathrm{P}$ values are examined, it is seen that this hypothesis is not accepted. In other words, it was determined that the series are heterogeneous (Table 5).

Table 5. Homogeneity test

\begin{tabular}{c|c|c}
\hline Test & Test statistic & Probability value \\
\hline$\Delta$ & 5.412 & 0.000 \\
$\Delta_{\text {adj. }}$ & 5.898 & 0.000 \\
\hline
\end{tabular}

\section{Panel causality analysis}

Because the series were heterogeneous in the current study, Dumitrescu and Hurlin (2012) Granger Panel Causality Test was applied. The main advantages of this method are that it can take into account the cross-section dependence between the countries that make up the panel, it can be used when the time dimension (T) is larger or smaller than the cross-section dimension $(\mathrm{N})$, and it can produce effective results in unbalanced panel data sets (Gülmez, 2015). The test statistic of this test is as follows:

$$
y i t=\alpha i+\sum_{k=1}^{K} \gamma i^{(k)} y i, t-k+\sum_{k=1}^{K} \beta i^{(k)} x i, t-k+\varepsilon i, t
$$

In the current study, a bidirectional causality relationship was determined between agricultural added value and organic agricultural area (Table 6).

Table 6. Panel causality analysis results

\begin{tabular}{c|c|c|c}
\hline Ho & W-bar Stat. & Z-bar Stat. & Z-bar tilde \\
\hline organic_area does not Granger-cause value_added & 3.0749 & $4.4015^{*}$ & $3.1306^{*}$ \\
value_added does not Granger-cause organic_area & 2.6917 & $3.5887^{*}$ & $2.5062^{* *}$ \\
\hline
\end{tabular}

\footnotetext{
$*, * *$ indicate the Granger causality at $1 \%$ and $5 \%$ significance level, respectively, lag order:1
} 


\section{Auto-regressive distributive lag cointegration test}

Since agricultural value added and organic area series were stationary at different degrees (I(0) and $\mathrm{I}(1)$ ), the relationship between them was investigated with ARDL model. Mean Group Estimator (MG) and Pooled Mean Group Estimator (PMG) were used to determine the relationship between agricultural added value and organic area, and Hausman test was used to determine which estimator's results would be taken into account.

The PMG estimator is a robust estimator that can cope with the omitted variable bias, endogeneity problem and country heterogeneity problem, and allows the long- and shortterm coefficients to be calculated separately (Kar and Kar, 2019). This estimator allows estimating the long- and short-term coefficients together and accepts the long-term coefficients the same for all units, while allowing the short-term coefficients to change from unit to unit and averaging (Güven and Mert, 2016). The panel PMG estimator allows variables of different stationarity to be estimated in the same model. This estimator calculates the short-term and long-term relationships along with the error correction coefficient (Dam and Şanl1, 2019).

The format of the PMG model is as follows (Kutlar, 2017):

$$
\begin{gathered}
\Delta Y_{i, t}=\phi E C_{i, t}+\sum_{i=0}^{q-1} \Delta X_{i, t-j}{ }^{\prime} \beta_{i, j}+\sum_{i=1}^{p-1} \lambda_{i, j} \Delta y_{i, t-j}+u_{i, t} \\
E C_{i, t}=y i, t-1-X_{i, t}^{\prime} \theta
\end{gathered}
$$

In this model, independent variables and dependent variables have the same time lag for each cross-section. But this is not a mandatory condition (Kutlar, 2017).

Panel ARDL estimation results are presented in Table 7. When PMG results are analysed, it is seen that organic agriculture has a positive effect on agricultural added value in the long-term. When the error correction term was examined, the coefficient was found to be negative and significant at the $1 \%$ level. In the short term, the relationship between the two variables was found to be statistically insignificant at the 5\% level. When the MG results were examined, it was determined that the organic farming area has no effect on the agricultural added value, neither in the short-term nor in the long-term (Table 7).

Table 7. Panel ARDL estimation results

\begin{tabular}{c|c|c}
\hline Long-term coefficient & PMG & MG \\
\hline organic_area & 103.2494 & 565.7876 \\
Error correction coefficient & $(0.000)$ & $(0.095)$ \\
& & -0.7302669 \\
ECT & -0.6256404 & $(0.000)$ \\
Short-term coefficient & $(0.000)$ & \\
organic_area (D1) & & -295.6065 \\
\end{tabular}

Values in parentheses are $\mathrm{p}$ values 
As can be seen, PMG and MG analyses yielded different results. For this reason, the Hausman test was used to determine which estimator's results would be taken as a basis. As the $\mathrm{p}$ value was greater than 0.05 in the Hausman test, it was determined that the PMG results were valid (Table 8 ). In other words, organic farming has a positive effect on agricultural added value in the long-term.

Table 8. Hausman test results

\begin{tabular}{c|c|c|c|c}
\hline & mg & pmg & Difference & S.E. \\
\hline fertilizer & 565.7876 & 103.2494 & 462.5381 & 388.8182 \\
\hline
\end{tabular}

$\operatorname{chi} 2(1)=1.42$, Prob $>$ chi $2=0.2342$

As a result of cointegration tests, long-term relationships between variables are estimated with the help of error correction models. If the error correction parameter is negative and significant, there is a long-term relationship between the variables (Tatoğlu, 2020). When the error correction coefficients by countries were analyzed separately, it was determined that there is a long-term relationship between organic farming area and agricultural added value in all the countries except for Spain and the Netherlands at different levels of importance (Table 9).

Table 9. Error correction coefficients by country

\begin{tabular}{c|c|c|c|c}
\hline Countries & Coefficients & Standard Error & $\mathbf{z}$ & $\mathbf{p}$ \\
\hline Germany & -0.8154798 & 0.2564646 & -3.18 & 0.001 \\
Austria & -0.8835147 & 0.2465509 & -3.58 & 0.000 \\
France & -1.01852 & 0.2540947 & -4.01 & 0.000 \\
Spain & -0.1878386 & 0.213034 & -0.88 & 0.378 \\
Italy & -1.169897 & 0.2588712 & -4.52 & 0.000 \\
Greece & -0.2872759 & 0.1386241 & -2.07 & 0.038 \\
Netherlands & -0.0257895 & 0.0673751 & -0.38 & 0.702 \\
Denmark & -0.8731309 & 0.2592194 & -3.37 & 0.001 \\
Sweden & -0.3693185 & -0.3693185 & -2.09 & 0.036 \\
\hline
\end{tabular}

\section{Discussion}

In the current study conducted to determine whether there is a relationship between organic farming area and agricultural added value in some European Union countries, a positive relationship was determined between organic farming area and agricultural added value. When the literature was reviewed, no study investigating the relationship between organic agriculture and agricultural added value was found. However, studies on the subject indicate that organic agricultural production creates higher added value. Polushkina et al. (2020) found that Russia's GDP increased significantly as a result of value-added organic agriculture. In the study conducted by Saracin and Vasile (2015), it is stated that organic products create added value. In the research conducted by Sanders (2016), organic milk supply chain, organic apple supply chain and organic pasta supply chain in 9 European Union countries were examined and it was determined that higher added value occurred in the organic food chain compared to the conventional food chain. 


\section{Conclusion}

Through organic agriculture, the use of chemicals in agricultural production is prevented, which makes significant contributions to the protection of the environment, nature and agricultural lands. In addition, organic agriculture has positive effects on human health, as consumers eat food that does not contain chemical inputs. On the other hand, organic agriculture can make significant contributions to the national economy.

Dynamic panel ARDL model was used in the current study carried out to determine the relationship between agricultural added value and organic farming area in 9 European Union countries for the period of 2000-2018. As a result of the statistical analyses, a significant positive relationship was determined between the organic farming area and the agricultural added value in the long term in the countries examined. In the short term, the relationship between the two variables was found to be statistically insignificant at the 5\% significance level. In the current study, a bidirectional causality relationship was also determined between agricultural added value and organic farming area. When an evaluation was made by country, it was determined that there is a long-term relationship at different levels of importance between organic farming area and agricultural added value in all the countries except for Spain and the Netherlands. This result is considered to be important for policy makers. Since a positive relationship was found between organic farming area and agricultural added value in the current study, supports to organic farming should be increased to make a positive contribution to agricultural added value. On the other hand, it is thought that it is necessary to carry out more studies that reveal the relationship between organic agriculture and agricultural added value.

\section{REFERENCES}

[1] Akyol, M. (2018): An examination of the relationship between agricultural incentives and agricultural added value: panel simulated equations system analysis for new industrialized countries. - The Journal of International Scientific Researches 3(3): 226-236.

[2] Altun, N. (2017): The empirical analysis of sustainability of budget deficit in Turkey: 19502015 era. - The International Journal of Economic and Social Research 13(1): 13-22.

[3] Ayla, D., Altıntaş, D. (2017): A review of organic production and marketing issues. Kastamonu University Journal of Faculty of Economics Administrative Sciences 19(4): 717.

[4] Bahsi, N. (2020): Investigation of factors affecting the organic agricultural production amount in Turkey: A panel data analysis. - Applied Ecology and Environmental Research 18(3): 4059-4073.

[5] Cukur, T. (2015): Conventional dairy farmers converting to organic dairy production in Turkey. - Polish Journal of Environmental Studies 24(4): 1543-1551.

[6] Dam, M. M., Şanl1, O. (2019): Impact of economic freedom on growth: a panel ARDL analysis on BRIC-T countries. - Atatürk University Journal of Economics and Administrative Sciences 33(4): 1027-1044.

[7] Dumitrescu, E. I., Hurlin, C. (2012): Testing for granger noncausality in heterogeneous panels. - Economic Modelling 29(4): 1450-1460.

[8] Erdinç, Z., Aydınbaş, G. (2021): Panel data analysis of value-added agriculture determinants. - Anadolu University Journal of Social Sciences 21(1): 213-232.

[9] FAO. (2021): Macro Indicators. - http://www.fao.org/faostat/en/\#data/MK (accessed on 08.06.2021).

[10] FIBL. (2021): Data on Organic Agriculture in Europe. https://statistics.fibl.org/europe.html (accessed on 08.06.2021). 
[11] Gül, E., İnal, V. (2017): Air pollution and economic growth relation: time-varying panel causality analysis. - The Sakarya Journal of Economics 6(2): 70-82.

[12] Gülmez, A. (2015): The relationship between economic growth and air pollution in OECD countries: A Panel Data Analysis. - Kastamonu University Journal of Faculty of Economics Administrative Sciences 9: 18-30.

[13] Güven, S., Mert, M. (2016): Cointegration analysis of international tourism demand: a panel ARDL approach to Antalya case. - Cumhuriyet Universtity Journal of Economics and Administrative Science 17(1): 133-152.

[14] Kar, B. B., Kar, M. (2019): Financial development and income inequality: a dynamic heterogeneous approach for BRICS economies. - Anadolu University Journal of Social Sciences 19(1): 27-46.

[15] Kripfganz, S., Schneider, D. C. (2016): ARDL: Stata module to estimate autoregressive distributed lag models. - 2016 Stata Conference 18, Stata Users Group.

[16] Kutlar, A. (2017): Panel Data Econometrics Applications with Step-by-Step Eviews. Umuttepe Publishing, Kocaeli (in Turkish).

[17] Pesaran, M. (2004): General Diagnostic Tests for Cross Section Dependence in Panels. IZA Discussion Paper, 1240.

[18] Pesaran, M. H., Yamagata, T. (2008): Testing slope homogeneity in large panels. - Journal of Econometrics 142: 50-93.

[19] Polushkina, T., Akimova, Y., Kovalenko, E., Yakimova, O. (2020): Organic agriculture in the system of the sustainable use of natural resources. - BIO Web of Conferences 17.

[20] Sanders, J., Gambelli, D., Lernoud, J., Orsini, S., Padel, S., Stolze, M., Willer, H., Zanoli, R. (2016): Distribution of the added value of the organic food chain. - Braunschweig: Thünen Institute of Farm Economics.

[21] Saracin, V. C., Vasile, A. (2015): An exploratory research regarding Romanian organic farming sector. - Agrolife Scientific Journal 4(2): 119-123.

[22] Tatoğlu, F. Y. (2020): Panel Time Series Analysis Stata Applied. - Beta Publishing, İstanbul. (in Turkish).

[23] Tatoğlu, F. Y. (2021): Panel Data Analyses - Lecture Notes. http://auzefkitap.istanbul.edu.tr/kitap/ekonometri_ue/panelverianalizi.pdf (accessed on 08.06.2021). (in Turkish). 